\title{
The Black Hawk War: Another View
}

\section{Edited by Roger L. Nichols}

The Black Hawk War of 1832 proved far more colorful and exciting to historians and interested amateur writers than to the men who struggled over muddy roads in northern Illinois and through the nearly trackless wilderness of southern Wisconsin pursuing the fleeing Sac and Fox Indians. One important point often overlooked, however, is that while Black Hawk and his followers crossed the Mississippi into Illinois, most members of these two tribes remained peaceably in Iowa and, in fact, even cooperated with the whites. The following episode portrays the difficulties facing those Indians who wished to remain at peace and the demands made upon them during this crisis.

In August, 1825, at mosquito-ridden Prairie du Chien, William Clark and Lewis Cass negotiated a treaty of peace and friendship with several Indian tribes living along the Mississippi River. Differing from the usual Indian treaty of that day, this document contained no terms for land cessions to the United States, but simply outlined the boundaries of each tribe's claim and established peace among the nations. Finally, almost as an afterthought, it included a clause which made the government responsible for maintaining this peace. Thus, while the concept of the "Great Father" settling the problems and quarrels of his "Indian children" was certainly benign, it involved the government, and through it the army, in nearly constant police activity along the frontier and, at the same time, produced even more discontent among those redmen wanting to settle differences by their own time-tested methods. In this situation, conflict became practically inevitable.

In the summer of 1831, bands of the Sac and Fox tribes attacked a Sioux camp and shortly afterward one of the Menominies. Raids by their long-time enemies enfuriated the Sioux even more than usual as the tribes involved were parties to a general peace treaty concluded at Prairie du Chien in July, 1830. The aggrieved tribes coupled their demand for redress with a threat to take matters into their own hands if 
the government did not abide by its commitments, one of which was to punish the offenders.

With these possible alternatives clearly set forth by the natives, William Clark and General Henry Atkinson, then commandant of Jefferson Barracks near St. Louis, both dispatched messages to their respective subordinates at Fort Armstrong on Rock Island, demanding the Sac and Fox surrender those responsible for the murders. At a council held there on September 5, 1831, the Indians refused compliance and plaintively asked, "why do you not let us be as the Great Spirit made us? and let us settle our own difficulties?" Thus the council failed, and, after the Indians left for their winter hunt, Atkinson and Clark recommended that efforts to apprehend the murderers be postponed until the following spring.

News of the Sac and Fox attack on the Menominies in August, 1831, and later reports from Indian Agents telling of Sioux and Menominie preparations for a retaliatory war the following spring caused official apprehension. General Alexander Macomb, Commanding General of the Army, ordered General Atkinson to "proceed forthwith to Fort Armstrong, with the efficient force now at Jefferson Barracks" and demand that the Sac and Fox surrender eight or ten of the leading men involved in the attack. If they refused, he was to "use the force to apprehend them or to take hostages..." While giving Atkinson full discretionary powers, Macomb suggested that the General move carefully so "that the Indians will see the object of the United States is to punish the guilty, not to injure the innocent."

Orders in hand, Akinson, a graying and portly career officer of 50, prepared to ascend the Mississippi with the 200 men then at Jefferson Barracks. Dealing with the Indians was nothing new for him as he often sat in on the councils held at the home of his close friend William Clark at St. Louis, and in 1825, serving as a joint commissioner to the tribes of the Upper Missouri district, he concluded 12 treaties while on the Yellowstone Expedition. In fact, the Indians knew the General well enough to have labeled him the "White Beaver."

As the troops moved up the Mississippi, Atkinson thought his task merely that of persuading the Sacs and Foxes to surrender a number of hostages and thus satisfy the Sioux 
and Menominie. Knowing many of the tribal leaders, he confidently expected this to be a simple, routine assignment. Enroute, however, he learned that Black Hawk and his band had recrossed the Mississippi into Illinois near the mouth of Rock River and that a full scale Indian war was possible. He promptly contacted the tribal leaders who remained on the Iowa side of the river, asking them to meet him at the Indian agency house on Rock Island on April 13, 1832.

That day, and again on April 19, he met the chiefs and leading men of the peaceful elements of the Sac and Fox tribes. In these negotiations the General demonstrated his knowledge of the Indians and his skill as a negotiator. While on one hand busily preparing for the eventuality of a war with Black Hawk, he carefully, but firmly demanded compliance with the President's orders. The Indians, at the same time, although probably unwilling and in part unable to comply with his demands, did manage to surrender fewer braves than called for, thus illustrating their skill as negotiators as well.

The minutes of these meetings give a vivid impression of the Indians' feelings, the difficulties they faced in trying to meet the General's demands, and finally, Atkinson's realization that a careless word might create enough resentment to enduce more bands within the tribes to join their refractory brethren east of the Mississippi.

The document used here is from the Mrs. Mason Barrett Collection in Tulane University Library. Except for placing the material in paragraphs and adding periods to those sentences having no punctuation, it remains unaltered.

Rock Island, 13th April, 1832

In a council held at Fort Armstrong Rock Island by Brig Genl Atkinson U. S. Army on the part of the Government of the U. States and Keokuk and the principal friendly Chiefs of the Sac \& Fox Tribes on the part of those Bands.

Br Genl Atkinson spoke as follows-_-_I am directed by you Great father to come here and place myself between the Menominies and Sioux and you (Sacs \& Foxes). Your Great father has been informed that the Menominies and sioux have been collecting together to come down and strike you. I will 
send to the Menominies \& sioux and tell them to stay at home. Your Great father will settle the difficulties between the

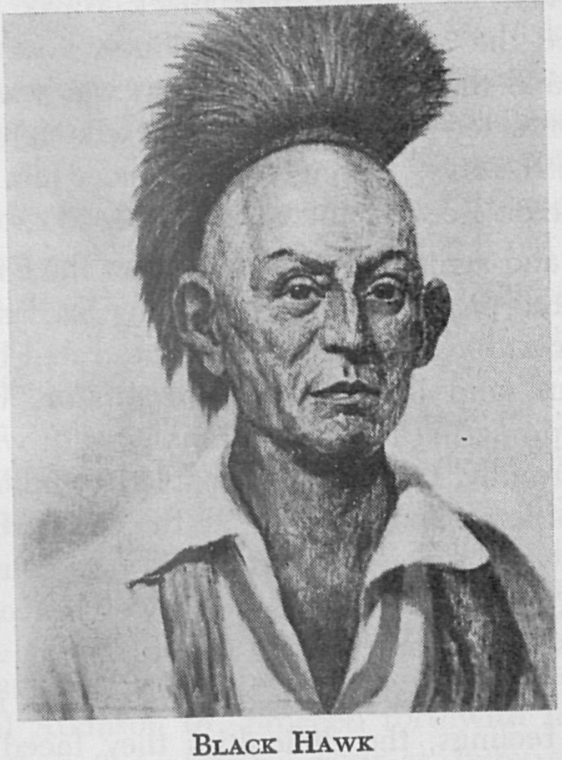

sioux \& Menominies and sacs \& Foxes. My Great father has directed me to tell the Menominies \& sioux that they shall listen to his voice! I will now tell you what your Great father has directed me to say to you. "The summer before last you made a treaty at Prairie du Chien. Many of you were present and signed that treaty-In violation of which some of your young men went up to Prairie du Chien and killed many Menominies. this has greatly displeased your Great father who says that at the same time that I compel the sioux and $\mathrm{Me}$ nominies to do right, I must also exact justice from the Sacs and Foxes. You must surrender Eight or ten of the murderers.

When I left home I had no information of the bad conduct of these people over here the band of the Black Hawk. I heard of it at the lower rapids. I care nothing for it. they can be as easily crushed as a piece of dirt-If they do not recross the river measures will soon be taken to compel them. I will not ask them to go back, I will not speak to them until they recross to the West bank of the Mississippi. I will treat them 
like dogs. I am not going to call them into council to tell me lies. Keokuk knows that his great father can cover these planes with men. ("Yes")-If Black Hawks band strikes one white man, in a short time they will cease to exist-I want to know how many indians have joined Black Hawk-

Ans. 500-

I am going myself to Prairie $\mathrm{Du}$ Chien to attend to the business with the Menominies-The Sacs \& Foxes who have not joined the band of Black Hawk must keep themselves away. They must not go where they are.

The Chiefs at the request of Genl. Atkinson withdrew, to the plain by themselves to deliberate. after remaining away about an hour they returned prepared to reply.

Keokuk first spoke, "We the chiefs and warriors of the Sac $\&$ Fox Nation do not know what to answer since we have been out.

You tell the truth with regard to the treaty. two years ago when Coln Morgan took us up to the Prairie, he made us make peace with the sioux. he told us to go up with them and he would arrange all Matters. We did not wish to make peace but we did make peace for fear of the americans. We acted from fear like whipped children and when he spoke at Prairie Du Chien he told me he would hold each village accountable for its own conduct-When Govr Clark went up he invited those indians over here (Black Hawks band) to go up and they would not. My Chief would not go. I went up. I got a copy of the treaty and explained it to my band and also to the Rock river Indians. my village and the British band do not like each other. they will not listen to us and that is the reason we do not know what to do-You say they must give themselves up or the chiefs must do it. we cant give them up it is out of [our] power. all of the Sacs engaged in the murder of the Menominies are of or with Black Hawks Party. We are unfriendly to that band. we will tell them what you say. last fall we had a meeting on invitations of Major Bliss \& our Agent. as soon as the council was over those who are with Black Hawks Party went away and we never could get them to speak with us since-If the war party had started from our village we would feel ourselves bound to give them 
up but as it is, we are unable-You wish us to keep at peace and have nothing to do with the Rock river indians. We will do so in token of our intentions. you see we have laid our spears there altogether. while you are gone to the Prairie we will endeavor to speak to them and try to persuade them to go back. if we do not succeed we can do no more. then, we will go home and try to keep our village at peace. The one who has raised all this trouble is a Winebago called the Prophet.

Prince the Chief of the Fox tribe next rose \& spoke to the following effect, "You have heard what my friend has said concerning the treaty at Prairie Du Chien and I will tell what I have heard from you to those chiefs that belong to Morgans village of Foxes. Its a pity that those who command this village are only boys. While you are gone to the Prairie I will tell them what you have said today. I do not doubt that they will say that "they do not know what to do. that is all I can say. Perhaps if I.were to promise more I could not do it-One of our young men was killed out here last fall by the sioux, menominies, \& Winebagoes. We judged so by some articles of ours and other Signs---

Question Where is Paukeeni--

Ans at Morgans Village. Natowitchika another principal man engaged in the murder is also there.

Why did not Morgans band come into council?

I do not know. the Agent sent for them. they said they would come here.

Were there more of sacs or Foxes engaged in the murder?

Answer--about equal numbers of each--

Genl Atkinson then replied as follows: When I told you that I would stand between the Menominies \& sioux and you, it was under the supposition that you be able to settle this difficulty. I can do nothing more than to tell the Menominies to wait till I hear from their Father again--I am instructed by your Great father to tell you that if you cannot give up the Murders you must give up hostages. I was told to take the hostages \& treat them kindly until the difficulty could be settled; if you think proper to leave some of your people here I will still stand between you and the Menominies. As you have been invited by me to come here I will not insist 
on it but leave it to your own good sense---they are not to be tried. they are to be kept 'till the Murderers are given up. hostages are required in order to show that you are disposed to do right.--The Winebagoes gave me hostages--When our difficulties were settled I gave them up-

Permission was granted young Apannose the son of a chief to speak at the request of Keokuk. Apannose--My father I came up in one of those boats with the troops. I tho't after seeing what would happen I would go \& tell the indians of it. I went into one of the leading Chiefs lodge (Napope). I began to talk to him gently, before I finished he stopped me and began to scold me violently. he did not strike me. that is all, he said, you will be very pitiful after a while. After I was so badly treated I went away to the braves lodge. I endeavored to get one of my female relations to come away. as soon as they found I was trying to get my relation away they sent a crier thro' the village telling the women and children not to go away that they would be happy and the rest miserable. I got there a little too late. the Prophets Message had been received, before I got there.

Question Where are the band of Black Hawk?

Answer--Near the hear of the rapid of rock river (6 or 8 miles hence).

Quest Where are they going?

Ans they would not tell me.

Quest. Where are their women \& children?

Answer with them.

Question How many men had they--

I could form no estimate and they would not tell me.

Question Where did they lie last night?

Ansr. Near a block house below the mouth of Rock river built by Genl Gaines--

Keokuk rose \& said you have just now listened to one of our chiefs sent below. you have heard the way our friends behave--that is the reason we never could fix this business. When you observed that [the] only way would be to give some up I thought I told you if they did not belong to our band we could do nothing with them. after hearing how our Message was received we consulted and thought we could 
not give ourselves up as we had nothing to do with the murder-We leave it to you to do with those chiefs what you can; We are now speaking to you here. if you will take notice, you will hear that we will be the first who are killed. We heard a good while ago that they were going to kill us. the man who cried in the village also said so.

I have only to add that we are going down to our villages to take care of ourselves. We are going to get $200 \mathrm{bags}$ of corn from the Traders. we hope you will not prevent it.

Genl Atkinson said Your Great father will not be satisfied. you ought do your part to give up the Foxes.

Keokuk answered I have nothing to do with the Foxes but I will attend to it--

The council then broke up. Genl Atkinson directed that Morgans band should be sent for \& appointed a meeting with the sacs \& Foxes on the 19th of April, and directed the chiefs that were present to remain 'till they came.

Rock Island 19th April 1832

The Sac \& Fox Nation friendly to the U. States being assembled near Fort Armstrong Genl. Atkinson met them there \& said I have been to Prairie Du Chien \& performed the business I went on. I have now returned to hear what you have to say.

Prince Wapalha (a Fox) My father we have heard what you told us that the President has sent you here \& after hearing what you said when you demanded the Murderers I told you I would try and you must not think hard if I failed--We have considered of it and have brought them in. Father there they are. There are the young men who have taken pity on the Women \& children-there are three of them. These are my chiefs. these are the Men who went into the braves lodge give themselves up-_-Father I have received these Young men. I now deliver them to you.

Keokuk then rose \& spoke. My father you have heard what my friend has told you. we the Sac \& Fox Nations are like brothers therefore you find us together as one Nation. You see us now-the Great spirit is looking at us and we hope he will help us to live on the other side of the river peaceablythree of our young men who went up with the party have 
given themselves up to their chief \& he has given them to you. I hope everything will be straight. Now that every thing is arranged at this place, I want with some of the chiefs to go down to see them tried. I shake hands with you in the presence of the father of all, he will be a witness that I am trying to do right.

Genl Atkinson said I am well pleased with what you have done. I expected you would have given up four men, but if you have done the best I am satisfied. I wanted to ge one half here and will have one half from them (B. H. band) before I am done--After I have fully ascertained what those people are doing I am going to St. Louis and these chiefs may go with me; as those young men have behaved so well who have given themselves up I shall treat them kindly--The chiefs of the Sacs \& Foxes on that side of the river (West) have also behaved well. I shall write to the President concerning them--I am going to St. Louis to make arrangements to settle the difficulties with those bad men over there. This is the second time that those bad men have opposed the prest. they were forgiven the first time, this time they will not. as sure as the sun shines on us at this moment they will be punished. You Keokuk know that it is easy to send 10,000 men in 1000 is not enough. I speak what you know is nothing but the truth-The friendly Sacs shall be protected \& supportedWhen I was at Prairie Du Chien I gave instructions to the commanding officer there to prevent either the Sioux or Menominies passing there. if they attempt it they will be opposed--the war party that attempted it was pursued by the troops and sent back--After every precaution some small Sioux party may try to get to you by land. this you must guard against. I did not tell the Winebagoes \& Sioux not to go against those bad men of Black Hawk. I do not care how many they kill-Advise your young men to keep on the West side of the river \& hold no communication with the unfriendly sacs.

Names of the indians delivered to Genl Atkinson and placed in confinement at Fort Armstrong: Kakikakanuck-Son of the Kettle, chief of the soldiers, Payckakanamuta-The one that we do not know, Mameykay, Wolf-- 
Copyright of Annals of Iowa is the property of State of Iowa, by \& through the State Historical Society of Iowa and its content may not be copied or emailed to multiple sites or posted to a listserv without the copyright holder's express written permission. However, users may print, download, or email articles for individual use. 